\title{
Pengaruh Kemudahan Informasi Dan Kualitas Informasi Terhadap Keputusan Bersedekah Di Masjid - Masjid Kota Batam
}

\author{
Yusuf Faisal $^{(1)}$ \\ Fakultas Ekonomi, Universitas Batam, Indonesia \\ yusuffaisal@univbatam.ac.id
}

Egi Gumala Sari ${ }^{(2)}$

Fakultas Ekonomi, Universitas Batam, Indonesia egigumalasari@gmail.com

\begin{abstract}
Abstrak Penelitian ini bertujuan untuk mengetahui sejauh mana pengaruh kenyamanan informasi dan kualitas informasi berpengaruh pada keputusan untuk memberikan amal. Metode analisis yang digunakan dalam penelitian ini adalah analisis kuantitatif dengan metode analisis regresi berganda. Sebelumnya dilakukan uji validitas, uji reliabilitas menggunakan nilai koefisien Alpha Cronbach. Berdasarkan hasil analisis yang dilakukan, dapat disimpulkan bahwa secara parsial (uji-t) variabel Kemudahan Informasi berpengaruh signifikan terhadap keputusan pemberian dan kemudahan informasi memiliki pengaruh positif dan signifikan terhadap keputusan pemberian di Batam. masjid. Hasil pengujian simultan (uji F) menunjukkan bahwa variabel kemudahan informasi dan kualitas informasi secara bersama-sama memiliki pengaruh positif dan signifikan terhadap keputusan pemberian. Koefisien R2 yang disesuaikan sebesar 0,401, yang berarti bahwa variabel tersebut dapat dijelaskan oleh kemudahan informasi dan variabel kualitas informasi sebesar $40,1 \%$, sedangkan sisanya 59,9\% dapat dijelaskan oleh variabel lain di luar model.
\end{abstract}

Kata kunci: Kemudahan Informasi, Kualitas Informasi, Keputusan Bersedekah

\section{PENDAHULUAN}

Masjid mempunyai fungsi dan peranan yang sangat besar bagi kaum muslimin, dan mempunyai arti yang sangat luas dalam berbagai aspek kehidupan. (Basit, 2009), (Robiatul Auliyah, 2009). Masjid merupakan barometer kegiatan kaum muslimin. Fungsi utama masjid adalah tempat sujud kepada Allah Subahanu Wa Ta'ala, tempat salat dan tempat beribadah kepada-Nya. (Hartanto, 2019), (Huda \& Fauzi, 2019), (Putra \& Rumondor, 2019). Di samping sebagai tempat ibadah, masjid juga berfungsi membina dan mendidik manusia menjadi insan yang beriman, bertakwa, berilmu, beramal saleh, berakhlak dan menjadi warganegara yang baik serta bertanggung jawab selaku makhluk Allah Subahanu Wa Ta'ala di muka bumi. (Nurhidayati et al., 2019), (Ramadhan et al., 2019), (Hartanto, 2019), (Fitriani, 2017). Sebagaimana Rasulullah ketika selesai membangun masjid Quba, lalu beliau melanjutkan perjalanannya ke Madinah. Sesampainya di Madinah yang pertama beliau lakukan adalah membangun masjid.(Muh 
Said, 2016) Masjid itu diberi nama dengan masjid Nabawi. Di dalam masjid inilah Rasulullah membina dan mengurusi segala kepentingan umat. Dari berbagai kultur masyarakat, ras dan multi agama beliau berhasil membina masyarakatnya, yang pada akhirnya beliau dikagumi dan disegani oleh semua pihak, baik kawan maupun lawan.

Hal ini bisa terjadi karena Rasulullah bisa mengelola, mengatur dan menjadikan masjid berfungsi dan berperan untuk berbagai macam kegiatan di antaranya :

1. Masjid sebagai pusat ibadah. Di dalam masjid dilakukan dan dilaksanakan berbagai macam kegiatan ibadah, baik ibadah mahdah maupun ghairu mahdah. Ibadah mahdah seperti salat wajib, salat sunat dan lain sebagainya. Dan setiap hari jum'at diadakan shalat jum'at dan khutbah jum'at untuk membina keimanan, ketakwaan, kepribadian dan hukum - hukum syari'at Islam.

2. Nabi menyelesaikan perkara dan pertikaian dalam masjid. Masjid dijadikan tempat menyidangkan soal - soal hukum dan peradilan dan tempat untuk menyelesaikan persoalan - persoalan masyarakat dan negara. Pada zaman khalifah Umar, Dewan seperti pertimbangan agung, melakukan sidang - sidangnya di masjid. Begitu juga pada zaman khalifah Abu Bakar dalam menyelesaikan administrasi pemerintahan dilakukan di masjid.

3. Masjid sebagai pusat pendidikan dan pengajaran. Sebagaimana Rasulullah sering menerima wahyu di masjid, dan beliau mengajarkan kepada sahabat sahabatnya. Dan di masjid juga diadakan ruang dan tempat perpustakaan untuk mendalami ilmu - ilmu, mengadakan diskusi, penelitian, kajian - kajian ilmiah dan lain sebagainya. Karena Islam merupakan sumber inspirasi bagi pengembangan ilmu pengetahuan dan tekhnologi. Karena wahyu pertama menganjurkan untuk beriqra' yaitu membaca, meneliti, melihat dan mengadakan penelitian - penelitian.

4. Nabi dan sahabat mengatur strategi dan taktik perang di masjid. Seolah - olah ia merupakan markas besar tentara. Hal ini tergambar ketika Sa'ad luka parah dalam perang parit, maka ia meninggal di kemah yang berada di pekarangan masjid.

5. Masjid sebagai pusat informasi Islam. Rasulullah dalam menyampaikan berbagai macam informasi senantiasa di mulai dari masjid. Apakah informasi itu terkait dengan berbagai masalah agama maupun masalah negara atau masalah lainnya.

6. Sebagai tempat sosial Masjid juga berfungsi sebagai tempat orang musafir yang tengah dalam perjalanan. Waktu seorang budak wanita dibebaskan, dalam ketiadaan tempat tinggal, ia mengembangkan kemahnya di pekarangan masjid.

7. Di masjid ditempatkan baitul mal / kas negara, atau kas masyarakat muslim, untuk diatur dan dikelola dalam rangka mensejahterakan kehidupan sosial masyarakat muslim.

8. Ibnu sabit mendeklamasikan sajak - sajaknya dalam masjid ketika membela nabi yang dicemoohkan oleh lawannya.

9. Penghulu atau Qadi memimpin upacara pernikahan di masjid. Masjid berfungsi sebagai tempat untuk mendamaikan orang yang berselisih dalam berumah tangga dan sebagai mahkamah perceraian

Mengelola masjid pada zaman sekarang ini memerlukan ilmu dan ketrampilan manajemen. (Aisyah, 2013) Pengurus masjid (takmir) harus mampu menyesuaikan diri dengan perubahan zaman. Kenyataan yang dirasakan oleh peneliti di zaman sekarang ini kita merasakan bahwa kebanyakan masjid masjid kita ini dari tahun ke tahun mengalami 
krisis yang sangat memprihatinkan.; Pertama krisis kepengurusan (Hentika, 2014), Kedua krisis keuangan (Basit, 2009), Ketiga krisis sarana dan program (Achiria et al., 2018), hal ini nampak dari kegiatan masjid yang berorientasi pada hal-hal yang sifatnya ubudiyah yaitu sholat dan pendidikan seperti majlis ta'lim itupun belum tertangani dengan baik seperti penyiapan imam dan khotib yang baik, Keempat krisis remaja masjid (Basit, 2009) dalam arti dari sekian banyak remaja disekitar masjid, hanya sedikit saja yang mau aktif dalam kegiatan remaja masjid. Kelima, krisis jamaah (Jumhan, 2019), (Ramadhan et al., 2019), krisis ini nampak dari kurang semangat atau kurang antusiasnya jamaah masjid untuk ikut serta dalam berbagai kegiatan dimasjid.

Kualitas menjadi salah satu kunci dalam stategi demi meraih hati dari para muzakki yang ada. Agama Islam mengajarkan kepada umatnya yang melakukan kegiatan usaha untuk selalu memberikan kualitas pelayanan terbaik kepada pelanggan adalah salah satu kegiatan yang sangat mulia dimata Allah Subahanau Wa Ta'ala dan bagi siapa saja yang melakukannya akan mendapatkan kemulian dan kebaikan dari apayang telah dikerjakan. Nilai-nilai keislaman dalam memberikan pelayanan kepada konsumen perlu diterapkan (Satria \& Ridlwan, 2019) yakni fathanah yang ditunjukan dengan profesional, shidiq yang ditunjukan dengan nilai kejujuran, tabligh yang ditunjukan dengan perilaku sopan dan ramah dalam mmberikan pelayanan, dan amanah yang ditunjukan dengan jaminan dan kenyamanan dalam memberikan pelayanan kepada konsumen. Dalam penelitian terdahulu kualitas layanan (Tho'in, 2011), (Sofwan, 2013), (Amalina, 2017), (Muliana, 2017) dan kemudahan informasi (Mahardika, 2018), (Andarsari, 2017), (Rahayu, 2017), (Katili \& Kamaru, 2018), (Susantok et al., 2019) menjadi faktor konsumen menentukan menggunakan suatu jasa yang ditawarkan oleh suatu lembaga, kualitas layanan berpengaruh secara positif terhadap keputusan menggunakan suatu jasa. Muzakki dalam akan membandingkan dengan yang mereka harapkan. Seorang konsumen akan meninggalkankan pemberi jasa apabila layanan yang mereka terima berada sangat jauh di bawah yang mereka harapkan. Berbeda situasi ketika seorang konsumen diberikan pelayanan yang lebih dari harapan mereka maka konsumen terserbut akan menggunakan jasanya kembali. Sehingga dapat dirumuskan masalah yakni apakah kemudahan informasi dan kualitas informasi terhadap keputusan bersedekah

\section{Landasan Teori}

\section{Kemudahan Informasi}

Kata kemudahan merupakan kata sifat yang memilki kata dasar mudah. (Amijaya, 2000) faktor kemudahan didefinisikan sebagai tingkat dimana seseorang meyakini bahwa penggunaan sistem informasi adalah mudah dan tidak memerlukan usaha keras dari pemakainya untuk dapat melakukaannya. Oleh karena itu berdasarkan penelitian yang telah dilakukan oleh Davis daat dikatakan bahwa dalam mengembangkan sebuah sistem informasi perlu dipertimbangkan faktor kebermanfaatan dan kemudahan dari pengguna sistem informasi. (Monisa, 2013). Menurut Davis (Taylor \& Todd, 1995), indikator kemudahan infroamsi meliputi :

1) mudah untuk dipelajari (easy to learn).

2) dapat di kontrol (controllable).

3) jelas dan dapat dimengerti (clear and understandable).

4) fleksibel (flexible).

5) mudah untuk menjadi mahir (easy to become skillful). 
6) mudah digunakan (easy to use)

\section{Kualitas Informasi}

Kualitas informasi adalah "tingkat dimana informasi memiliki karakteristik isi, bentuk, dan waktu, yang memberikannya nilai buat para pemakai akhir tertentu”. (O’Briens \& Marakas, 2005). (Juran \& Godfrey, 1998) mengatakan bahwa kualitas adalah pemenuhan terhadap kepuasan konsumen. kepuasan konsumen merupakan salah satu tolak ukur dari kualitas. Pada awalnya ukuran kualitas layanan ini didesain untuk mengukur kepuasan pelanggan oleh (Parasuraman et al., 1994). Mereka mendefinisikan kualitas layanan sebagai perbandingan antara harapan pelanggan dan persepsi merekatentangkualitas layanan pelanggan yang diberikan. Apabila pengguna sistem informasi masjid merasakan bahwa kualitas layanan yang diberikan oleh takmir baik, maka ia akan cenderung untuk merasa puas bersedekah. Diprediksi bahwa semakin tinggi kualitas layanan yang diberikan akan berpengaruh terhadap makin tingginya - tingkat kepuasan pengguna.

\section{Keputusan Bersedekah}

Secara umum, keputusan adalah pemilihan dari dua atau lebih alternative pilihan (Schiffman \& Kanuk, 1997) Dengan kata lain untuk membuat keputusan harus terdapat alternatif pilihan. Sebaliknya jika konsumen tidak memiliki alternatif untuk memilih maka tidak dapat dikategorikan sebagai pengambilan keputusan.

Faktor-faktor yang memberikan pengaruh terhadap keputusan (Becker et al., 2007), (Marteau, 1989) adalah sebagai berikut:

a. Perbedaan individu terdiri dari beberapa kategori, yaitu:

1) Sumberdaya konsumen;

2) Pengetahuan;

3) Sikap;

4) Motivasi;

5) Kepribadian, nilai yang dianut dan gaya hidup;

b. Pengaruh lingkungan, meliputi:

1) Budaya;

2) Kelas Sosial;

3) Pengaruh Pribadi;

4) Pengaruh Keluarga;

5) Situasi;

c. Proses psikologi, terdiri dari:

1) Pengolahan Informasi;

2) Pembelajaran;

3) Perubahan Sikap dan prilaku;

Sadaqah salah satu perilaku konsumsi dalam Islam seperti halnya Zakat dan infaq, sehingga teori tentang faktor-faktor yang mempengaruhi keputusan konsumen dapat juga digunakan untuk menentukan faktor-faktor yang mempengaruhi keputusan seseorang untuk bersedekah. Berdasarkan penelitian (Aulia et al., 2012) menyebutkan variabel yang mempengaruhi perilaku kepatuhan sedekah adalah: 
a. Komitmen kepada agama

b. Kepahaman/pengatahuan

c. Kemudahan mekanisme pembayaran

d. Kepercayaaan kepada institusi

e. Lingkungan

\section{METODE PENELITIAN}

Penelitian ini bertujuan untuk mengetahui sejauh mana pengaruh kemudahan informasi dan kualitas informasi berpengaruh terhadap keputusan bersedekah. Penelitian ini termasuk dalam penelitian kuantitatif bisa dikatakan juga penelitian empiris yang akan menguji hipotesis yang dikemukakan sebelumnya. Tingkat intervensi peneliti dalam penelitian ini termasuk pada tingkat intervensi minimal. Lingkungan risetnya termasuk dalam non-contrived setting. Unit analisis yang digunakan dalam penelitian ini adalah orang yang bersedekah yang berdomisili di Kota Batam. Penelitian ini menggunakan studi cross sectional yang dilakukan pada Desember 2019 sampai Januari 2020.

Populasi dan Sampel Penelitian adalah seluruh orang yang menyedekahkan hartanya di masjid - masjid Kota Batam. Teknik pemilihan sampel dilakukan dengan metode convenience sampling yaitu suatu prosedur untuk mendapatkan unit sampel menurut keinginan peneliti. (Zikmund, 2013). Penelitian ini menggunakan Kuesioner dengan pertanyaan / pernyataan tertutup yakni dimana diberikan kepada responden secara langsung atau dikirim melalui grup WhatsApp sehingga ditemukan 330 kuesioner yang disebar sebagai sampel penelitian ini yang kembali kepada penulis hanya sejumlah 140 responden untuk dianalisa lebih lanjut

Metode analisis yang digunakan dalam penelitian ini adalah analisis kuantitatif dengan alat analisis berupa regresi berganda. Sebelumnya dilakukan uji validitas Pearson product-moment, coefficient of correlation dan reliabilitas dengan menggunakan nilai koefisien Cronbach Alpha. Analisis regresi linear berganda dapat dirumuskan sebagai berikut:

$\mathrm{KB}=\beta+\beta_{1} \mathrm{KI}+\beta_{2} \mathrm{KUI}+\mathrm{e}$

Dimana:

$\mathrm{KB}=$ Keputusan Bersedekah

KI $\quad=$ Kemudahan Informasi

KUI = Kualitas Informasi

$\beta=$ Konstanta

Untuk melakukan regresi linier berganda dengan uji signifikansi, yaitu dengan alat uji T-test dan F-test.

1. T-test untuk menguji pengaruh secara parsial.

$\mathrm{H}_{1}=$ Terdapat pengaruh kemudahan informasi terhadap keputusan bersedekah $\mathrm{H}_{2}=$ Terdapat pengaruh kualitas informasi terhadap keputusan bersedekah

2. F-tes, untuk menguji pengaruh secara bersama-sama atau simultan.

$\mathrm{H}_{3}=$ Terdapat pengaruh kemudahan informasi dan kualitas informasi terhadap keputusan bersedekah

\section{HASIL DAN PEMBAHASAN}


Pada bagian ini akan menjelaskan mengenai hal-hal yang berkaitan dengan data data yang berhasil dikumpulkan, hasil pengolahan data dan pembahasan dari hasil pengolahan data.

\section{Deskripsi Data}

Populasi dalam penelitian ini adalah masyarakat yang menyedekahkan hartanya ke masjid - masjid di Kota Batam, Data dalam penelitian ini diperolah dengan cara mengantarkan langsung kuisioner kepada responden atau melalui google form yang di kirim melalui whatsApp yang terpilih. Pengumpulan data dilakukan sejak tanggal 17 Desember sampai tanggal 17 Januari 2020.

Sampel dalam penelitian ini berjumlah 330 responden. Dari pengembalian kuisioner yang disebarkan, 140 kuisioner yang diterima kembali dapat di lanjutkan untuk analisis data. Terdapat kuisioner yang tidak dapat diolah dikarenakan responden tidak memberikan penilaian terhadap semua pernyataan dalam kuisioner dan tidak memberikan jawaban sama sekali.

\section{Deskripsi Responden}

Dari 140 kuisioner yang dapat diolah, gambaran umum responden yang terinci pada tabel 4.1 dilihat dari jenis kelamin responden, laki - laki 117 orang $(83,57 \%)$ dan perempuan 23 orang (16,53\%), artinya sebagian besar responden adalah laki - laki. Dilihat dari tingkat pendidikan responden, SMA sederajat sebanyak 56 orang (40\%), pendidikan terakhir sarjana sebanyak 47 orang $(33,57 \%)$, pendidikan terakhir magister sebanyak 31 orang $(22,14 \%)$ dan juga terdapat responden yang berpendidikan terakhir doktoral sebanyak 6 orang $(4,29 \%)$ hal ini berarti sebagian besar responden adalah orang yang berpendidikan tinggi danmampu untuk memahami pertanyaan dalam kuisioner dan berkompeten dalam memberikan jawaban. Serta dilihat dari usia responden yang mayoritas masih muda yakni pada usia 19 tahun sampai 40 tahun dibandingkan usia 41 59 tahun. Hal ini menunjukkan di usia muda semangat bersedekah telah tertanam di dalam diri.

Tabel 1 : Deskripsi Responden

\begin{tabular}{|c|l|l|c|c|}
\hline No & \multicolumn{1}{|c|}{ Karakterstik } & Katagori & Frekuensi & Persentase \\
\hline 1 & Jenis Kelamin & Laki - & 117 & 83,57 \\
& & Laki & 23 & 16,43 \\
& & Perempuan & & \\
\hline 2 & \multirow{2}{*}{ Tingkat Pendidikan Terakhir } & SMA & 56 & 40,00 \\
& & Sarjana & 47 & 33,57 \\
& & Magister & 31 & 22,14 \\
& & Doktor & 6 & 4,29 \\
\hline 3 & usia & $19-30$ & 44 & 31,43 \\
& & $31-40$ & 60 & 42,86 \\
& & $41-50$ & 32 & 22,86 \\
& & $51-59$ & 4 & 2,86 \\
\hline
\end{tabular}

Sumber : SPSS Data yang telah diolah dari Kuesioner

\section{Uji Kualitas Data}


Uji Validitas Uji validitas dilakukan untuk mengukur sah atau valid tidaknya suatu kuesioner. Suatu item dikatakan valid jika pernyataan pada kuesioner mampu untuk mengungkapkan sesuatu yang akan diukur oleh kuesioner tersebut. Ghozali (2011).

Berdasarkan tabel 4.2 yang merupakan ringkasan dari hasil uji validitas dapat diketahui bahwa instrument - instrumen pada setiap variabel dalam penelitian ini adalah valid. Hal ini dibuktikan dengan nilai Pearson Correlation yang nilainya lebih besar dari 0,388 .

Tabel 2 : Uji Validitas

\begin{tabular}{|l|l|c|c|c|c|}
\hline No & Variabel & $\begin{array}{c}\text { Butir } \\
\text { Pertanyaan }\end{array}$ & $\mathrm{R}_{\text {hitung }}$ & Ketentuan & Keterangan \\
\hline 1 & Kemudahan & $\mathrm{X}_{1 .}$ & 0,550 & $0,550>0.388$ & Valid \\
& Informasi & $\mathrm{X}_{1.2}$ & 0,632 & $0,632>0.388$ & Valid \\
& & $\mathrm{X}_{1.3}$ & 0,741 & $0,741>0.388$ & Valid \\
& & $\mathrm{X}_{1} .4$ & 0,631 & $0,631>0.388$ & Valid \\
& & $\mathrm{X}_{1} .5$ & 0,613 & $0,613>0.388$ & Valid \\
& & $\mathrm{X}_{1} .6$ & 0,543 & $0,543>0.388$ & Valid \\
& & $\mathrm{X}_{1 .}$ & 0,628 & $0,628>0.388$ & Valid \\
\hline 2 & Kualitas & $\mathrm{X}_{2 .}$ & 0,605 & $0,605>0.388$ & Valid \\
& Informasi & $\mathrm{X}_{2 .}$ & 0,651 & $0,651>0.388$ & Valid \\
& & $\mathrm{X}_{2.3}$ & 0,640 & $0,640>0.388$ & Valid \\
& & $\mathrm{X}_{2.4}$ & 0,761 & $0,761>0.388$ & Valid \\
& & $\mathrm{X}_{2.5}$ & 0,610 & $0,610>0.388$ & Valid \\
& & $\mathrm{X}_{2.6}$ & 0,583 & $0,583>0.388$ & Valid \\
\hline 3 & Keputusan & $\mathrm{Y} 1$ & 0,425 & $0,425>0.388$ & Valid \\
& Bersedekah & $\mathrm{Y} 2$ & 0,697 & $0,697>0.388$ & Valid \\
& & $\mathrm{Y} 3$ & 0,704 & $0,704>0.388$ & Valid \\
& & $\mathrm{Y} 4$ & 0,478 & $0,478>0.388$ & Valid \\
& & $\mathrm{Y} 5$ & 0,710 & $0,710>0.388$ & Valid \\
& & $\mathrm{Y} 6$ & 0,660 & $0,660>0.388$ & Valid \\
\hline
\end{tabular}

Sumber : SPSS Data yang telah diolah dari Kuesioner

Pada penelitian ini juga dilakukan Uji Reliabilitas dimana Suatu kuesioner dikatakan reliabel jika jawaban seseorang terhadap pernyataan adalah konsisten dari waktu ke waktu.Uji reliabilitas dilakukan dengan menggunakan uji statistik Cronbach Alpha. Suatu instrumen dikatakan reliabel apabila nilai Cronbach Alpha lebih besar dari nilai 0,60 maka instrumen yang digunakan reliabel. (Ghozali (2011). Berdasarkan Tabel 3 berikut ini dapat dilihat bahwa seluruh variabel dalam penelitian ini reliabel. Hal ini dibuktikan dengan nilai Cronbach Alpha $>0,60$

Tabel 3 : Uji Reliabilitas

\begin{tabular}{|l|c|c|c|}
\hline \multicolumn{1}{|c|}{ Variabel } & Cronbach's Alpha & Ketetuan & Keterangan \\
\hline Kemudahan Informasi & 0,714 & $0,714>0,60$ & Reliabel \\
Kualitas Informasi & 0,764 & $0,764>0,60$ & Reliabel \\
Keputusan Bersedekah & 0,703 & $0,703>0,60$ & Reliabel \\
\hline
\end{tabular}

Sumber : SPSS Data yang telah diolah dari Kuesioner 


\section{Analisis Regresi Linear Berganda}

Pengujian hipotesis dalam penelitian ini menggunakan analisis regresi linear berganda dengan bantuan program SPSS 22. Hasil dari regresi linear berganda dalam penelitian ini dapat dilihat pada Tabel 4 berikut:

Tabel 4. Regresi Linear Berganda

\begin{tabular}{|c|c|c|c|c|c|}
\hline \multirow[t]{2}{*}{ Model } & $\begin{array}{c}\text { Unstandardized } \\
\text { Coefficients }\end{array}$ & \multirow[t]{2}{*}{$\begin{array}{l}\text { Std. } \\
\text { Error }\end{array}$} & $\begin{array}{l}\text { Standardized } \\
\text { Coefficients }\end{array}$ & \multirow[t]{2}{*}{$\mathrm{t}$} & \multirow[t]{2}{*}{ Sig } \\
\hline & $\mathrm{B}$ & & Beta & & \\
\hline (Constant) & 17,067 & 3,986 & & 4,282 &, 000 \\
\hline KEI & ,354 & 020 & ,657 & 17,297 &, 000 \\
\hline KUI &, 175 & ,064 &, 140 & 2,716 & ,008 \\
\hline $\mathrm{R}^{2}$ & \multicolumn{2}{|c|}{ Adjusted $\mathrm{R}^{2}$} & \multicolumn{2}{|l|}{$\mathrm{F}$} & Sig. \\
\hline 0,430 & \multicolumn{2}{|l|}{0,401} & \multicolumn{2}{|l|}{3,029} & 0,039 \\
\hline
\end{tabular}

Sumber : SPSS Data yang telah diolah dari Kuesioner

Uji statistik F menunjukkan apakah semua variabel independen yang dimasukkan dalam model mempunyai pengaruh secara simultan terhadap variabel dependen. Apabila nilai signifikansi (lebih kecil dari $\alpha=0,05$ ) berarti bahwa variabel independen secara bersamaan memiliki pengaruh terhadap variabel dependen. Berdasarkan tabel tersebut dapat dilihat bahwa dalam penelitian ini variabel independen mempunyai pengaruh secara bersamasama terhadap variabel independen dengan nilai signifikansi 0,039.

Nilai adjusted $\mathrm{R}^{2}$ menunjukkan seberapa besar variabel dependen dapat dijelaskan oleh variabel independen. Nilai adjusted R 2 dapat dilihat pada tebel 4.4 yaitu sebesar 0,401 . Hal ini menunjukkan bahwa dalam penelitian ini variabel dependen yang dapat dijelaskan oleh variabel independen sebesar 40,1\%, sedangkan sisanya yaitu sebesar 59,9 $\%$ dijelaskan oleh variabel lain yang tidak termasuk dalam penelitian ini.

Uji t digunakan untuk mengetahui pengaruh masing-masing variabel independen terhadap variabel dependen. Hipotesis diterima jika nilai signifikansinya lebih kecil dari 0,05 dan hipotesis ditolak jika nilai signifikansinya lebih besar dari 0,05.

Dari tabel persamaan rumus regresi linier berganda dapat diperoleh hasil sebagai berikut:

$$
\mathrm{Y}=17,067+0,354 \mathrm{X}_{1}+0,175 \mathrm{X}_{2}
$$

Hasil persamaan regresi berganda tersebut diatas memberikan pengertian bahwa:

a. Nilai konstanta 17,067 mempunyai arti bahwa apabila variabel-variabel bebas yaitu kemudahan informasi, kualitas informasi, itu konstan atau tidak berubah maka keputusan bersedekah bernilai positif

b. $b_{1}$ (nilai koefisien regresi $X_{1}$ ) 0,354 mempunyai arti bahwa terdapat pengaruh positif antara kemudahan informasi yang diberikan terhadap keputusan bersedekah masyarakat di Kota Batam. Sehingga diharapakan Informasi yang disajikan takmir masjid sebaiknya mencakup informasi berkaitan dengan kegiatan pembangunan dan jasa yang ada di masjid - masjid Kota Batam. Informasi tersebut sebaiknya berguna dan relevan dalam memprediksi kualitas dan kegunaan produk atau jasa. Untuk memuaskan orang - orang bersedekah, informasi laporan keuangan dan juga kegiatan 
harus up-to-date, membantu orang - orang yang bersedekah dalam membuat keputusan, sehingga konsisten untuk terus bersedekah. Masjid - masjid di Kota Batam sebaiknya menyajikan informasi yang mencakup kaitannya dengan laporan keuangan dan kegiatan yang ada secara sistematis dan simultan. Sehingga masyarakat dapat dengan mudah mendafpatkan Informasi tersebut untuk memprediksi orang - orang akan terus bersedekah di masjid tersebut.

c. $\mathrm{b}_{2}$ (nilai koefisien regresi $\mathrm{X}_{2}$ ) 0,175 mempunyai arti bahwa terdapat pengaruh signifikan kualitas informasi yang diberikan terhadap keputusan bersedekah masyarakat. Kulitas informasi yang baik akan memberikan rasa kepercayaan yang diberikan adalah wilayah psikologis yang merupakan perhatian untuk menerima apa adanya berdasarkan harapan terhadap perilaku yang baik dari orang lain. Hasil penelitian ini menjelaskan bahwa pada umumnya orang - orang yang bersedekah akan memperhitungkan kualitas infromasi yang dapat diperoleh dari uang yang akan mereka keluarkan. Kualitas Informasi yang baik bukanlah berdasarkan sudut pandang atau persepsi pihak penyedia jasa, melainkan berdasarkan sudut pandang atau persepsi konsumen, konsumenlah yang mengkonsumsi dan menikmati jasa, sehingga merekalah yang seharusnya menetukan informasi yang diberikan.

\section{Kesimpulan}

Berdasarkan hasil analisis yang dilakukan, maka dapat disimpulkan bahwa secara parsial (uji-t) variabel Kemudahan Informasi berpengaruh signifikan terhadap keputusan bersedekah dan kualitas infromasi berpengaruh positif dan signifikan terhadap keputusan bersedekah di dimasjid - masjid Batam. Hasil pengujian secara simultan (uji F) menunjukkan bahwa variabel kemudahan informasi dan kualitas informasi secara bersama-sama berpengaruh positif dan signifikan terhadap keputusan bersedekah Koefisien Adjusted $\mathrm{R}^{2}$ sebesar 0.401, yang berarti bahwa variabel dapat dijelaskan oleh variabel kemudahan infromasi dan kualitas informasi sebesar 40,1\%, sedangkan sisanya sebesar 59,9\% dapat dijelaskan oleh variabel-variabel lain diluar model. Diharapkan masjid - masjid dapat memberikan kemudahan informasi dan infromasi berkualitas yang up to date (terkini), akurat dan lengkap. Bagi peneliti lanjutan diharapkan hasil penelitian ini dapat dijadikan referensi untuk penelitian yang sejenis serta diharapkan peneliti selanjutnya menambah atau meneliti variabel lainnya yang kemungkinan

\section{DAFTAR PUSTAKA}

Achiria, S., Priyadi, U., \& Fahmi, R. A. (2018). Pelatihan Manajemen Masjid Di Desa Argodadi, Sedayu, Bantul, Yogyakarta. Prosiding Seminar Nasional Seri 8, 265271.

Aisyah, S. (2013). Membangun Kekuatan Ekonomi Masjid. Jurnal Syari'ah, 2(2), 5162.

Amalina, D. (2017). Faktor Yang Mempengaruhi Proses Pengambilan Keputusan Wisatawan Berkunjung Ke Objek Wisata Religi Masjid Agung Islamic Centre Kabupaten Rokan Hulu. Progress in Physical Geography, 4(2), 1-19. https://doi.org/10.1177/0309133309346882 
Amijaya, G. R. (2000). Pengaruh Persepsi Teknologi Informasi, Kemudahan, Resiko Dan Fitur Layanan Terhadap Minat Ulang Nasabah Bank Dalam Menggunakan Internet Banking. Interfaces, 30, 117-118.

Andarsari, P. R. (2017). Laporan Keuangan Organisasi Nirlaba (Lembaga Masjid). Ekonika: Jurnal Ekonomi Universitas Kadiri, 1(2), 143-152. https://doi.org/10.30737/ekonika.v1i2.12

Aulia, F. R., Zulkifli, D., \& Sanep, Ahmad. (2012). Model Perilaku Kepatuhan Zakat: Suatu Pendekatan Teori. Iqtishoduna, Mueller 1986. https://doi.org/10.18860/iq.v0i0.1744

Basit, A. (2009). Strategi Pengembangan Masjid Bagi Generasi Muda. KOMUNIKA: Jurnal Dakwah Dan Komunikasi, 3(2), 270-286. https://doi.org/10.24090/komunika.v3i2.130

Becker, D. V., Kenrick, D. T., Neuberg, S. L., Blackwell, K. C., \& Smith, D. M. (2007). The confounded nature of angry men and happy women. Journal of Personality and Social Psychology, 92(2), 179-190. https://doi.org/10.1037/0022-3514.92.2.179

Fitriani, F. (2017). Peranan Dan Fungsi Perpustakaan Masjid Dalam Mencerdaskan Umat Islam. Pustaka Karya: Jurnal Ilmiah Ilmu Perpustakaan Dan Informasi, 5(10), 52. https://doi.org/10.18592/pk.v5i10.1619

Hartanto, S. (2019). The Prosperity Of The Mosque Concepts. Journal Ecoplan, 2(2), 9098. https://doi.org/10.1017/CBO9781107415324.004

Hentika, N. (2014). Meningkatkan Fungsi Masjid Melalui Reformasi Administrasi (Studi Pada Masjid Al Falah Surabaya). Jurnal Administrasi Publik Mahasiswa Universitas Brawijaya, 2(2), 305-311.

Huda, M., \& Fauzi, A. (2019). Sistem Pengelolaan Wakaf Masjid Produktif Perspektif Hukum Islam (Studi Kasus di Masjid Ismailiyyah Nalumsari Jepara). Jurnal AtTamwil, 1(2), 27-46.

Jumhan, A. (2019). Menghidupkan Shalat Berjamaah Di Masjid Nurul Jannah Serikembang Iii Kecamatan Payaraman Kabupaten Ogan Ilir. Suluh Abdi: Jurnal Ilmiah Pengabdian Kepada Masyarakat (2019), 1(2), 98-102. https://doi.org/10.1017/CBO9781107415324.004

Juran, J., \& Godfrey, A. (1998). Juran's Quality Handbook, 5th Edition. In Juran's Quality Handbook, 5th Edition.

Katili, A. Y., \& Kamaru, I. (2018). Transparansi Pemanfaatan Dana Bantuan Oleh Badan Ta'mirul Masjid Asshabirin Di Desa Ilohuuwa Kecamatan Bone Kabupaten Bone Bolango. Jurnal Manajemen Sumber Daya Manusia, Administrasi Dan Pelayanan Publik, 5(1), 35-43.

Mahardika, B. T. (2018). Analisis Dan Perancangan Sistem Informasi Managemen Masjid Berbasis Web ( Studi Kasus : Yayasan Masjid Darul Maarif Daaima Jakarta ). Jurnal Teknologi Informasi, 4(2), 1-12.

Marteau, T. M. (1989). Framing of information: Its influence upon decisions of doctors and patients. British Journal of Social Psychology, 28(1), 89-94. https://doi.org/10.1111/j.2044-8309.1989.tb00849.x

Monisa, M. (2013). Persepsi Kemudahan Dan Kegunaan Opac Perpustakaan Unair. Juirnal Unair, 2(1), 1-6. http://journal.unair.ac.id/download-fullpapers-Jurnal Martina.pdf 
Muh Said, N. (2016). Manajemen Masjid ( Studi Pengelolaan Masjid Agung Al-Azhar Jakarta ). Jurnal Tabligh, 84-96.

Muliana, H. (2017). Hubungan Antara Kualitas Layanan Perpustakaan Masjid Dengan Tingkat Kepuasan Pemustaka Pada Perpustakaan Masjid Pusat Dakwah Islam (Pusdai) Bandung. Edulibinfo, 3(1), 21-29.

Nurhidayati, W., Mufidah, E., Addaai, N., Ishom, A., \& Choirul, M. (2019). Sejarah Sosial Pendidikan Islam Pada Era Kenabian. Jurnal Pendidikan Islam, 8(1), 1-12.

Parasuraman, Zeithaml, V., \& Berry, L. (1994). Alternative Scales for Measuring Service Quality: A Comparative Assessment Based on Psychometric and Diagnostiv Criteria. Journal of Retailing, 70(3), 201-230.

Putra, A., \& Rumondor, P. (2019). Eksistensi Masjid Di Era Rasulullah. Tasamuh, 17(1), 245-264. https://doi.org/10.20414/tasamuh.v17i1.1218

Rahayu, R. A. (2017). Tranparansi dan Akuntabilitas Pelaporan Keuangan Masjid Agung Al-Akbar Surabaya. Jurnal Reviu Akuntansi Dan Keuangan, 4(2), 631-638. https://doi.org/10.22219/jrak.v4i2.4948

Ramadhan, A., Hasanah, I., \& Hakim, R. (2019). Potret Masjid Sebagai Basis Pemberdayaan Ekonomi Umat. Iqitishodia: Jurnal Ekonomi Syariah, 4(1), 31-49.

Robiatul Auliyah. (2009). Studi Fenomenologi Peranan Manajemen Masjid At-Taqwa Dalam Pemberdayaan Ekonomi Masyarakat Bangkalan Robiatul Auliyah. Jurnal Studi Manajemen, 2005.

Satria, P. N., \& Ridlwan, A. N. (2019). Pengaruh Kualitas Layanan Dan Promosi Terhadap Keputusan Donatur Membayar Zis Di Surabaya. Jurnal Ekonomi Islam, 2(3), 64-71.

Schiffman, L., \& Kanuk, L. L. (1997). Comportamento Do Consumirdor (Issue 7).

Sofwan, R. (2013). Penguatan Manajemen Pemberdayaan Fungsi Masjid Al-Fattah di Kelurahan Krapyak Semarang. DIMAS: Jurnal Pemikiran Agama Untuk Pemberdayaan, 13(2), 315-334.

Susantok, M., Darwis, R. S., \& Akbar, M. (2019). Implementasi teknologi papan informasi digital pada Masjid Al Bayan Kelurahan Limbungan Baru Kecamatan Rumbai Pesisir Kota Pekanbaru. Unri Conference Series: Community Engagement, 1, 511-517. https://doi.org/10.31258/unricsce.1.511-517

Taylor, S., \& Todd, P. (1995). Assessing IT usage: The role of prior experience. MIS Quarterly: Management Information Systems, 19(4), 561-568. https://doi.org/10.2307/249633

Tho'in, M. (2011). Pengaruh Faktor-faktor Kualitas Jasa terhadap Kepuasan Nasabah di Baitul Mal Wat Tamwil (BMT) Tekun Karanggede Boyolali. Muqtasid: Jurnal $\begin{array}{lllll}\text { Ekonomi Dan Perbankan } & \end{array}$ https://doi.org/10.18326/muqtasid.v2i1.73-89

Zikmund, W. G. (2013). Business Research Methods. In Cengage Learning. https://doi.org/10.1063/1.3033960 